\title{
Agama Dan Pembentukan Cara Pandang Serta Perilaku Hidup Masyarakat
}

\author{
Joko Santoso*, Yossita wisman \\ Fakultas Keguruan dan Ilmu Pendidikan, Universitas Palangka Raya, Indonesia \\ Email: joko_santosa@pasca.upr.ac.id
}

Diterima: 06 Mei 2020; Disetujui: 15 Mei 2020; Diterbitkan: 18 Mei 2020

\begin{abstract}
ABSTRAK
Agama merupakan salah satu faktor paling menentukan dalam mempromosikan nilai dan keutamaan hidup dalam masyarakat. Manusia dan Agama merupakan pasangan yang senantiasa mewarnai kehidupan. Tidak ada manusia yang tidak beragama, agama merupakan bagian kehidupan manusia. Pada saat Agama mempengaruhi kehidupan, disaat yang sama perilaku akan berpengaruh pada kehidupan seseorang. Melalui ajaran-ajaran dan praktik-praktik religiusnya, agama mengarahkan cara pandang manusia dan masyarakat. Dalam artikel ini penulis hendak mendiskusikan bagaimana agama memainkan peran pembentukan cara pandang tersebut. Penulis memfokuskan kajian ini pada kegiatan ritual, Kitab Suci dan ajaran etika yang secara umum dijalankan dalam setiap agama dalam mengajarkan nilai-nilai. Tujuan dari pembahasan ini adalah untuk mengangkat kesadaran pembaca tentang relevansi agama dalam hidup manusia dan pentingnya memerhatikan isi ajaran-ajaran agama demi mempromosikan kebaikan bersama bagi semua alam ciptaan.
\end{abstract}

Kata kunci: agama, ajaran etika, cara pandang dan kitab suci, perilaku, ritual

\section{PENDAHULUAN}

Hubungan antara agama dan kehidupan sehari-hari kadang tidak disadari oleh kebanyakan orang. Agama sering dianggap sebagai instrumen spiritual yang hanya mengurus relasi dengan Yang Ilahi dan menyentuh aspek rohaniah dari kehidupan masyarakat semata. Sehingga agama dianggap tidak memiliki kontribusi dalam kehidupan konkret manusia dalam ranah sosial, politis, ekonomis maupun budaya. Pandangan seperti ini tentu sangat mereduksi peran dan keberadaan agama dalam kenyataan hidup bersama. Agama dilepaskan dari keseluruhan wilayah kehidupan manusia.

Dalam artikel ini penulis memotret pemandangan yang lebih utuh dan menyeluruh dari peran agama dalam kehidupan bermasyarakat, teristimewa peran agama dalam membentuk cara pandang seseorang dalam memahami dan menanggapi situasi hidup yang dihadapinya. Cara pandang ini, pada level selanjutnya, akan menentukan perilaku hidup orang tersebut secara konkret. Saling keterkaitan seperti ini menunjukkan bahwa agama tidak terkungkung pada level kegiatan spiritual belaka, melainkan juga mengarah pada aktualisasi dan implementasi konkret dalam tataran hidup praktis.

Pemaparan dalam artikel ini hendak difokuskan pada tiga elemen penting yang biasanya dilestarikan oleh setiap agama, yaitu pertama, kegiatan ritual, misalnya doa pribadi maupun doa bersama, ziarah, sakramen, perayaan hari suci, 
dan sebagainya; kedua, kitab suci yakni teks-teks yang dianggap suci dan diyakini berisi ajaran-ajaran ilahi yang disampaikan kepada penganut agama yang bersangkutan dan telah diwariskan dari zaman ke zaman; ketiga, etika atau ajaran tentang yang baik dan yang jahat atau hal-hal yang harus dilakukan dan yang tidak boleh dilakukan oleh seseorang dalam hidupnya. Pada umumnya, ketiga elemen ini dikembangkan oleh semua agama besar dunia, yang secara langsung maupun tidak langsung memengaruhi hidup masyarakat dan menentukan arah peradaban.

\section{METODE PENELITIAN}

Artikel ini ditulis melalui penelitian atas bahan-bahan pustaka (library research) yang relevan dengan topik mengenai agama, cara pandang, dan perilaku. Buku yang relevan tersebut disebutkan secara terperinci dalam daftar pustaka pada akhir artikel. Sedangkan beberapa kutipan penting akan dicantumkan dan dirujuk di sepanjang pembahasan artikel. Gagasan yang diperoleh dari referensi tersebut membantu penulis mengembangkan ide-ide yang tertuang dalam buah pemikiran sebagaimana dipaparkan sebagai satu kesatuan dalam artikel ini.

\section{HASIL PENELITIAN DAN PEMBAHASAN \\ Cara Pandang dan Perilaku Manusia}

Perilaku manusia sangat ditentukan oleh cara pandangnya tentang realitas di sekitarnya. Cara pandang dibangun oleh nilai-nilai, keutamaan, prinsip hidup yang diyakini seseorang. Cara pandang terbentuk lewat proses pembelajaran yang dilalui oleh seseorang sepanjang hidupnya. Berbagai institusi sosial -termasuk agama- sangat membantu mengarahkan proses pembelajaran dan pembentukan cara pandang ini. Menurut Peoples dan Bailey (2006:32), "Cara pandang seseorang adalah cara ia mengartikan kenyataan dan peristiwa, termasuk gambaran mengenai diri sendiri dan bagaimana ia berhubungan dengan dunia sekitar." Ishii, Cooke, dan Klopf (1999:301-317) mengembangkan suatu definisi yang lebih luas dengan menyatakan "Cara pandang merupakan orientasi budaya terhadap Tuhan, sesama, alam, pertanyaan tentang keberadaan sesuatu, alam dan kosmos, kehidupan, moral dan alasan etis, penderitaan, kematian, dan isu filosofis lainnya yang memengaruhi bagaimana anggotanya memandang dunia." Walsh dan Midleton (1984:32) meringkaskannya dengan menyatakan, "Cara pandang menyediakan petunjuk yang menuntun pengikutnya di dunia." Singkatnya, cara pandang berisi prinsip-prinsip dasar yang dijunjung tinggi seseorang dalam hidupnya. Cara pandang merupakan inti dari perilaku, inti dari karakter seseorang dan menyediakan dasar persepsi yang diyakini seseorang atas realitas yang dihadapi dan dihidupinya. Karakter cara pandang yang demikian menjadi salah satu faktor paing signifikan dalam menentukan perilaku hidup seseorang.

Cara pandang tersebut kemudian mengatur hidup dan menunjukkan arah bagi hal-hal praktis dalam kehidupan. Hoebel (1958:159) mengamati "Dalam memilih kebiasaan hidup sehari-hari, bahkan dalam hal terkecil sekalipun, masyarakat memilih cara yang sesuai dengan pemikiran dan kesukaannya -cara yang sesuai dengan aturan dasar sesuatu serta yang diinginkan dan yang tidak diinginkan." Demikian besarnya pengaruh dari cara pandang, maka dapat dikatakan bahwa pandangan hidup seseorang menentukan kehidupan sosial, ekonomi, dan politik suatu negara. 


\section{Hubungan Antara Agama dan Cara Pandangan Pemeluknya}

Agama mengambil peran yang sangat penting dalam pembentukan cara pandang. Hal ini pertama-tama disebabkan karena agama menyentuh hal-hal mendasar dari hidup manusia. Ajaran agama berisi panduan yang menjadi penuntun hidup para pemeluknya. Ajaran agama menggeluti hal- hal yang bermakna bagi hidup yang terungkap dalam dialektika tentang pertanyaan dan jawaban terhadap pencarian makna hidup setiap manusia.

Cara pandang menyangkut pertanyaan-pertanyaan dasar dalam kehidupan, seperti berikut. Siapakah saya? Siapakah manusia itu? Dari mana saya berasal? Ke mana saya akan berakhir? Mengapa saya harus hidup? Apakah tujuan hidup manusia? Apakah dunia ini diatur oleh hukum, atau secara kebetulan, atau oleh 'Tuhan'? Bagaimanakah cara hidup yang benar? Bagaimanakah dunia ini dimulai? Bagaimanakah dunia ini akan berakhir? Apakah yang akan terjadi setelah kita meninggal dunia? Apa yang terjadi dengan jiwa kita setelah kematian? Mengapa ada penderitaan dalam hidup ini? Mengapa dunia ini fana? Mengapa ada kebaikan dan kejahatan? Apa akibat dari dosa? Bagaimana dosa dapat diampuni? Bagaimana kita bisa selamat?

Pertanyaan-pertanyaan tersebut dikenal juga sebagai pertanyaan-pertanyaan eksistensial, yaitu pertanyaan yang tidak dapat, tidak perlu ditanyakan. Kebanyakan orang, mulai dari lahir sampai meninggal, menanyakan pertanyaan yang sama dan menghadapi tantangan yang sama mengenai kebingungan dan ketidakpastian hidup. Seperti yang dituliskan oleh Osborne (1996: ix), "Semuanya mengekspresikan kekaguman dan kerendahan hati atas misteri alam semesta." Mulai dari kisah penciptaan (misal: pada kitab Kejadian dalam Alkitab) sampai mengenai deskripsi lengkap mengenai surga dan neraka, semua agama menolong manusia untuk memahami asal manusia, alasan mereka ada di dunia, yang terjadi ketika manusia meninggal, dan alasan adanya penderitaan. Singkatnya, agamalah yang menyediakan jawaban dari pertanyaan sulit dan universal ini.

Pertanyaan-pertanyaan tersebut adalah pertanyaan-pertanyaan mutlak (ultimate questions) yang menyangkut eksistensi hidup manusia. Oleh karena itu, pasti akan ditanyakan oleh setiap orang dalam hidupnya teristimewa pada momenmomen spesial dalam perjalanan hidupnya. Agama memberi pencerahan dan jawaban mengenai pertanyaan-pertanyaan ini. Dengan cara itu, agama menentukan cara pandang dan perilaku hidup para pemeluknya. Peran agama dalam menjawab pertanyaaan-pertanyaan eksitensial semacam ini sangatlah krusial. Itu karena manusia selaku makhluk spiritual selalu terarah untuk menanyakan hal ini. Manusia selalu berpaling kepada agama untuk menemukan jawaban dan peneguhan atas aspirasinya dalam menjawab panggilan batin dan pencarian makna hidupnya ke arah transendensi diri.

Hubungan antara Agama, cara pandang, dan perilaku pemeluk agama telah banyak digeluti oleh para filsuf, para teolog, maupun para ahli ilmu sosial lainnya seperti yang pernah ditunjukkan secara menonjol oleh sosiolog, Max Weber, dalam The Protestant Ethic and the Spirit of Capitalism. Weber menunjukkan bahwa ajaran Protestantisme tentang 'panggilan' (the calling) yang menekankan pada kesejahteraan hidup manusia sangat memengaruhi perkembangan kapitalisme di Eropa pada zamannya. Agama memengaruhi kegiatan produksi, perdagangan, dan proses bisnis lainnya. Max Weber mengungkapkan pengamatannya bahwa agama tidak terlepas dari kehidupan sosial bahkan tidak terlepas 
dari peradaban modern, hal yang masih berlangsung sampai sekarang ini.

Agama terbentuk sedemikian rupa sehingga sebagai suatu institusi pranata sosial menjadi instrumen yang cukup handal dalam melestarikan nilai-nilai, termasuk mempromosikan dan menegakkan nilai-nilai itu dalam implementasi yang konkret. Agama sebagai suatu institusi sosial menyediakan struktur, disiplin, dan partisipasi sosial dalam suatu komunitas. Agama memiliki klaim supernatural atas kekuasaannya dalam memberikan pengajaran. Klaim-klaim supernatural seperti ini pada umumnya secara efektif memampukan agama mendorong nilai-nilai untuk diyakini oleh para pemeluknya. Makin kuat keyakinan seseorang kepada agamanya, maka makin kuat juga pengaruh ajaran agama dalam hidup orang tersebut.

Kata 'agama' (religion) berasal dari terminologi bahasa Latin yang berbunyi religare yang berarti 'untuk mengikat'. Dari pengertian ini kita dapat merasakan pentingnya kekuatan kolektif agama. Agama mengikat para pemeluknya satu sama lain dalam satu identitas sekaligus mengikat mereka dengan hal-hal sakral termasuk dengan nilai-nilai yanag diajarkannya. Nilai-nilai ini menjadi bagian dari credo kehidupan mereka yang senantiasa diperjuangkan dalam kehidupan sehari-hari. Ikatan ini memperteguh kohesi sosial antarpemeluk agama tersebut sekaligus mempertegas identitas mereka. Berbagai simbol religius membantu menegaskan identitas ini. Simbol-simbol tersebut menyatukan sekaligus membedakan dengan yang lain, membangun kekhasan sekaligus memisahkan dari yang lain. Dengan demikian, agama menjadi suatu kekuatan sosial yang sangat signifikan. Dalam agama-agama besar dunia ikatan tersebut telah berlangsung lama dari zaman ke zaman melalui proses penyesuaian di sana-sini, tetapi tetap mempertahankan kekhasan. Dalam berbagai cara agama telah mengikat orang bersama-sama dan memelihara cara pandang mereka selama ribuan tahun. Agama mempertegas identitas para pengikutnya dan menyatakan kesatuan institusionalnya.

Kesatuan institusional tersebut mempertegas pula kekuatan agama dalam mengajarkan nilai- nilai dan membentuk cara pandang para penganutnya. Baik melalui institusi seperti gereja Katolik, pemimpin spiritual dan sosial seperti Buddha dan Confucius, maupun melalui ajaran Alkitab, Weda, Quran, Torah, dan I Ching, manusia selalu merasakan suatu kebutuhan untuk melihat ke luar diri mereka terhadap nilai-nilai yang mereka gunakan dalam mengatur hidup mereka. Para penganut agama setidak-tidaknya memperoleh pegangan untuk menanggapi pertanyaan-pertanyaan hidupnya berdasarkan ajaran-ajaran yang dilestarikan dan disampaikan oleh para pemimpin agamanya.

Sebagaimana yang telah disebutkan, keberadaan pertanyaan-pertanyaan kehidupan ini mempertegas relevansi agama dalam hidup manusia. Pengaruh agama masih akan terasa relevan karena agama berusaha menjawab pertanyaanpertanyaan transenden yang dihadapi manusia, antara lain tentang kematian, kekekalan, penderitaan, dan asal serta tujuan alam semesta. Seperti yang dituliskan oleh Malefijt (1968: 145), "Agama menyediakan penjelasan dan menunjukkan nilai dari fenomena yang tidak dapat dijelaskan." Agama juga menolong pengikutnya dalam menghadapi isu-isu yang berhubungan dengan hidup manusia. Isu tersebut teristimewa menyangkut tentang hal yang benar dan salah, memberikan legitimasi rohaniah dan supernatural, dan memberikan jaminan keselamatan. Hal demikian biasanya membawa dampak mengurangi stres dan frustrasi yang kadang mengarah pada konflik sosial. Sehubungan dengan hal ini, Nanda 
(1994:349) menunjukkan fungsi penting agama, yaitu agama "berhubungan dengan kehidupan dan kematian, penciptaaan alam semesta, asal masyarakat dan kelompok dalam masyarakat, hubungan antara seorang individu dan kelompok satu sama lainnya, dan hubungan dengan alam."

Agama memegang peranan yang sangat mendasar dari kehidupan manusia karena menyangkut dimensi paling hakiki dari diri manusia. Agama menggeluti, mengurusi, dan berupaya memenuhi kebutuhan rohani yang sulit dipenuhi oleh perangkat pemenuhan kebutuhan material dan sekuler termasuk oleh ilmu pengetahuan dan teknologi. "Sepanjang sejarah, agama merupakan sumber nilai paling kaya," demikian pernyataan Grondona (2000:47). Struktur dasar dari agama yakni pemujaan kepada Yang Ilahi pun tidak dapat dipisahkan dari kehidupan seharihari. Pemujaan mengarah kepada nilai-nilai dan nilai-nilai tersebut dihidupi dalam praktik hidup yang konkret. Agama dan perilaku tidak dapat dipisahkan. Agama tidak hanya berkutat dengan hal-hal transendental ataupun hal-hal yang bersifat surgawi dan akhirat semata, melainkan mendorong pemeluknya untuk memerhatikan hidupnya secara penuh kini dan di sini agar dapat memasuki realitas transenden yang dijanjikan pada masa sesudah kematian. Agama tidak hanya berhubungan dengan isu kosmis, tetapi juga berfokus pada masalah pribadi, masalah budaya, ekonomi, politik dan semuanya.

Sejarah menunjukkan bahwa agama berpengaruh atas peradaban dunia. Kita dapat menemukan buktinya, yang di dalamnya budaya Barat sangat diwarnai oleh oleh ajaran dan pengaruh politik Katolik dan Protestan; peradaban Srilanka dan Thailand sangat diwarnai oleh ajaran Buddha; peradaban di Timur Tengah sangat dipengaruhi oleh Islam; demikian pula Rusia dan Yunani oleh aliran Orthodoks di Rusia dan India yang mengandung pengaruh ajaran Hindu yang kental (Smart, 2000). Untuk memahami kebijaksanaan asing di Tibet, misalnya, seseorang perlu memahami terlebih dahulu mengenai monastisisme Buddha dan Dalai Lama. Untuk dapat memahami situasi politik di Timur Tengah seseorang perlu mendalami tradisi keislaman yang dijunjung tinggi oleh masyarakat di sana. Kenyataankenyataan ini menunjukkan bahwa kaitan antara agama dan budaya adalah sangat jelas. Agama dan peradaban saling bergandengan tangan dalam perjalanan evolusi dan perkembangan peradaban dunia. Agama mengambil andil dalam budaya dan kehidupan masyarakat.

Pentingnya memerhatikan kaitan agama dan cara pandang semakin terasa dalam konteks komunikasi lintas budaya, yang era globalisasi dewasa ini telah mempertemukan orang dari berbagai latar belakang agama dalam suatu interaksi yang semakin intens. Braswell (1994:3) menyatakan bahwa konteks hidup kita sekarang ini terbentuk sedemikian rupa sehingga, "Masyarakat beragama tidak lagi saling berjauhan. Penganut agama telah melintasi batas-batas geografis dan budaya untuk bertemu dan hidup bersama." Dengan kata lain, orang tidak lagi hidup tersekat-sekat berdasarkan agama. Sebaliknya, sekat-sekat pemisah antaragama atau antarpemeluk agama telah semakin pudar. Dunia sudah semakin plural dan tidak lagi terkotak-kotak berdasarkan agama, ideologi, ataupun bahkan suku bangsa. Manusia hidup dalam suatu dunia yang sangat globalized, yang di dalamnya manusia mau tidak mau berjumpa dengan orang-orang dari latar belakang agama yang berbeda-beda. Perjumpaan antaragama ini tentu melibatkan perjumpaan antarcara pandang. Lewat pemahaman yang lebih mendalam tentang isi agama masing-masing, maka orang akan semakin dibantu dalam hal me- 
mahami perilaku, sikap dan tindakan yang diambil oleh orang-orang yang ditemui sehari-hari.

Dunia berkembang sedemikian rupa sehingga sekarang ini kita saling bergantung satu sama lain. Yang terjadi di satu tempat di suatu belahan dunia dapat memengaruhi orang banyak di tempat yang lain. Kita hidup pada suatu masa perubahan teknologi, transportasi, sistem ekonomi dan politik, pola imigrasi, dan kepadatan penduduk telah menghadirkan suatu dunia yang kita secara teratur berinteraksi dengan orang lain dari budaya dan agama yang berbeda. Situasi ini akan berkembang terus dan makin intens. Latar belakang budaya dan agama ikut menentukan interaksi dan komunikasi interpersonal. Ajaran agama akan memengaruhi cara orang berinteraksi dan dinamika kehidupan sosial berjalan bahkan sampai pada level paling personal. Ajaran agama menjadi salah satu acuan dan pedoman pengarah tindakan konkret yang diambil oleh seorang pemeluk agama.

\section{Kitab Suci dan Pembentukan Cara Pandang}

Dalam setiap agama besar terdapat sejumlah kebijaksanaan yang sakral kebijaksanaan yang harus disampaikan kepada para pemeluk agamanya baik yang ada dulu, sekarang maupun generasi berikutnya. Kebijaksanaan dasar itu biasanya termaktub dalam teks suci yang dijunjung tinggi oleh agama yang bersangkutan. Teks suci tersebut biasanya disatukan sebagai satu kumpulan buku atau disebut juga Kitab Suci. Kitab suci menjadi sumber penting pengajaran dan pembentukan suatu doktrin yang menjadi rujukan bersama dalam mengarahkan hidup para anggotanya. Hal ini terjadi sedemikian rupa karena Kitab Suci dianggap menampung legitimasi transendental dari Yang Ilahi. Kitab Suci dianggap mengandung ajaranajaran ilahi, diinspirasi oleh Yang Ilahi sendiri, secara khusus, demi mengajari manusia hidup sesuai dengan kehendak Yang Ilahi. Ajaran-ajaran dalam Kitab Suci ditujukan untuk menata hidup personal maupun bersama agar dengan demikian para penganut agama dapat mencapai kesempurnaan hidup dan akhirnya beroleh 'keselamatan' dari dunia yang fana ini menuju hidup dalam persekutuan dengan Yang Ilahi, yaitu hidup yang diidealkan dalam setiap agama dan yang diidamkan serta dicari oleh setiap pemeluk agama.

Penting untuk memerhatikan bahwa kata 'suci' digunakan dalam menjelaskan kitab tersebut. Matthews (2007:4) dengan jelas mengidentifikasi alasan kata tersebut digunakan: "Setiap agama memercayai bahwa kitab sucinya tersebut berasal dari Tuhan atau diilhami oleh Roh Kudus, baik ditulis atau diucapkan oleh Allah, ditulis oleh manusia yang dituntun Tuhan, maupun diucapkan oleh guruguru spiritual." Hampir di semua peristiwa, 'pengetahuan' tersebut berhubungan langsung dengan individu yang dianggap memiliki kelebihan khusus. Pribadipribadi mulia ini disebut juga sebagai 'pendiri' agama. Mereka merupakan pribadi yang berwenang dalam menuntun dan memerintah. Bagi agama Yahudi, pribadipribadi tersebut ditemui dalam diri Abraham dan Musa. Dalam kepercayaan Islam, Al Quran dipercaya diwahyukan oleh Allah yang Maha Tinggi dan Maha Mengetahui yang menjadikan Muhammad sebagai perantara untuk menyampaikan pesannya yang penting. Dalam beberapa kasus, nasihat yang bijaksana berasal dari seorang filsuf seperti Buddha atau seorang yang bijaksana seperti Confusius. Bagi orang Kristen otoritas tersebut ada pada Yesus, "Putra Allah."

Figur-figur otoritas ini sangat berpengaruh dalam melegitimasi ajaran agama "karena mereka menemukan atau mendengar pesan atau ajaran dari Tuhan, dari 
dewa atau dari orang yang lebih bijaksana." (Richter, Rapple, Modschiedler, dan Peterson, 2005:10) Terlepas dari siapa pribadinya, semua tradisi memiliki seseorang sebagai teladan emosional dan spiritual. Figur-figur ini merupakan figur-figur penentu tradisi agama. Mereka antara lain menjadi pembangun identitas agama yang bersangkutan sekaligus menjadi model dan teladan pembentukan diri dari setiap pemeluk agama yang hendak memperjuangkan hidup yang sempurna.

Alkitab umat Kristen terdiri dari 39 kitab dalam Perjanjian Lama, ditulis dalam bahasa Ibrani, dan 27 kitab dalam Perjanjian Baru, ditulis dalam bahasa Yunani, menjadi dasar tertulis ajaran Kristen. Bagi orang Yahudi, Kitab Ibrani yang terdiri atas Perjanjian Lama, merupakan dokumen penting yang telah berlangsung selama ribuan tahun dan memberikan petunjuk hingga hari ini. Quran yang dipercaya oleh umat Islam diwahyukan oleh Allah kepada Nabi Muhammad, ditulis dalam bahasa Arab klasik. Bagi umat Muslim, menurut Crystal (2003:388), "menghafal ayat-ayat kitab suci sejak kecil juga merupakan perkenalan terhadap huruf." Dalam agama Hindu, kitab suci ini ditemukan dalam Weda, termasuk Bhagavad-Gita. Kitab ini terdiri dari berbagai macam teks dan ditulis dalam bahasa Sansekerta. Kanon Pali, secara oral, mengandung ajaran Buddha. "Pali menjadi bahasa kanon bagi pengikut Buddha dari berbagai negara, namun teks yang sama juga ditemukan dalam bahasa lain, seperti dalam bahasa Cina dan Jepang, ketika agama berevolusi." (Crystal, 2003:388) Bagi tradisi Confucius, orang berpegang pada Analect, sekumpulan karya yang selama berabad-abad membentuk pemikiran dan tindakan miliaran orang.

Kitab Suci merupakan instrumen paling sentral dalam pengajaran agama karena merupakan rujukan yang utama. Ajaran-ajaran inti dari setiap agama tersimpan di dalamnya. Penggalian dan penafsiran atas ajaran-ajaran inti ini dibuat demi mengontekstualisasikan ajaran-ajaran tersebut ke dalam situasi hidup kontemporer masyarakat. Setiap pengajaran yang setia dengan tradisi agama senantiasa diupayakan untuk menjaga konsistensi isinya sesuai dengan teks-teks dalam kitab suci.

\section{Kegiatan Ritual dan Pembentukan Cara Pandang}

Ritual agama, misalnya doa pribadi maupun doa bersama, ziarah, sakramen, perayaan hari suci, dan sebagainya memiliki otoritas memengaruhi perilaku penganutnya. Confucius, dalam Anaclet 8:2 (Crystal, 2003:224), menuliskan nilai ritual sebagai berikut, "Tanpa ritual, kesopanan itu berarti membosankan, kebijaksanaan itu berarti menakutkan; tanpa ritual, keberanian itu berarti suka bertengkar; tanpa ritual, keterusterangan itu menyakitkan." Ritual, baik itu kecil maupun besar, penting dipraktikkan dalam semua agama. Smart (2000:9-10) menyatakan hal ini sebagai berikut: "Kebanyakan menekankan ritual. Gereja Katolik menginstruksikan untuk menghadiri misa setiap minggu. Umat muslim diperintahkan untuk salat lima kali sehari. Umat Hindu dituntut untuk menghadiri ritual di kuil. Buddha Theravada diminta mengunjungi kuil untuk menghormati Buddha. Umat Protestan memiliki pelayanan puji-pujian dengan khotbah sebagai bagian penting dari ritualnya."

McGuire (2002:17) menyatakan: "Ritual terdiri atas tindakan simbolis yang mewakili arti religius." Ritual mengaktualisasikan simbol-simbol ke dalam tindakan-tindakan yang sakral. Lewat ritual, simbol-simbol dihidupi dan dirayakan. Peranan ritual bagi agama dan budaya dengan jelas dinyatakan oleh Malefijt 
(1968:193): "Ritual mengingatkan masa lalu, memelihara, dan menyampaikan dasar suatu masyarakat. Peserta dalam ritual tersebut diidentifikasi dengan masa lalu yang suci, sehingga mengabadikan tradisi ketika mereka menetapkan kembali prinsip di mana suatu kelompok hidup dan berperan." Dalam hal ini, ritual berperan penting menyatukan semua penganutnya. Ritual secara sangat efektif membangun identitas religius agama tertentu.

Dengan terlibat dalam ritual, setiap anggota tidak hanya mengingat dan menegaskan kepercayaan penting. Mereka juga merasa terhubung secara spiritual dengan agama mereka, mengembangkan rasa identitas dengan meningkatkan ikatan sosial dengan siapa mereka berbagi pandangan dan kenyataan bahwa hidup mereka memiliki arti dan struktur. Menurut Haviland, Prins, Walrath, dan McBride (2008:309), "Ritual atau tindakan seremonial secara alamiah bukanlah agama... Ritual berperan untuk membebaskan tekanan sosial dan menguatkan ikatan kolektif suatu kelompok. Lebih lanjut, ritual menyediakan cara untuk menandai peristiwa penting dan mengurangi gangguan sosial dan penderitaan individu karena krisis seperti kematian.” Ritual, seperti aspek budaya lainnya, tidak berdasarkan naluri, jadi agar dapat bertahan harus diturunkan dari satu generasi ke generasi berikutnya. Ritual dibuat dalam berbagai bentuk baik dalam tradisi menyalakan lilin atau dupa, mengenakan pakaian tertentu dan duduk, berdiri atau berlutut ketika berdoa. Ada ritual yang berhubungan dengan tempat (umat Muslim salat menghadap ke arah Mekah) dan yang lainnya memerhatikan perayaan (Umat Kristen merayakan Natal dan Paskah, dan umat Yahudi menandakan pentingnya Passover). Ritual dalam arti tertentu sangat efektif karena sedikit berbeda dengan doktrin agama yang lebih menyentuh aspek kognitif manusia. Ritual menyentuh diri manusia secara lebih menyeluruh termasuk aspek motorik maupun performatif dari doktrin, yang melaluinya ajaran-ajaran agama, nilai-nilai religius, dan bahkan gambaran ideal dan impian tertinggi manusia dihidupi dan dirayakan secara anggun dan seremonial.

Hal yang paling umum dari semua ritual adalah upacara inisiasi yang menandakan tahapan dalam siklus hidup manusia. Menurut Angrosino (2004:97), "Upacara pengalihan merupakan upacara sosial yang menandakan masa transisi anggota suatu kelompok dari satu tahap hidup yang penting ke tahap hidup yang berikutnya. Kelahiran, pubertas, pernikahan, dan kematian merupakan masa transisi yang penting dalam berbagai budaya." Dalam agama, berbagai ritus diselenggarakan untuk menandai transisi-transisi kehidupan. Dalam tradisi agama Katolik misalnya, terdapat sakramen permandian atau pembaptisan bagi anak yang baru lahir, kemudian sakramen konfirmasi dan ekaristi bagi anak remaja. Demikian pula ada sakramen pernikahan ataupun imamat bagi orang dewasa, dan sakramen pengurapan orang sakit bagi mereka yang berusia lanjut ataupun yang akan menghadapi kematian.

\section{Etika Agama dan Pembentukan Cara Pandang}

Salah satu tujuan mendasar dari keberadaan agama adalah untuk mengajari para pemeluknya tentang cara hidup yang sesungguhnya. Agama berusaha mengajarkan para pemeluknya tentang cara mencapai kesempurnaan hidup. Hal ini dilakukan lewat berbagai ajaran-ajaran etis tentang kehidupan yang ideal. Robinson dan Rodrigus (2006:14) mencatat, "Agama berperan penting dalam mengatur tindakan manusia. Hampir setiap tradisi agama membedakan antara tindakan 
yang dapat diterima dengan tindakan yang tidak dapat diterima." Ajaran mengenai etika yang berfokus pada hal yang benar dan salah menyatakan inti nilai suatu budaya. Dalam banyak hal, ikatan antara agama dan etika dapat dilihat dalam hukum agama yang spesifik. Dalam agama Yahudi, misalnya, tidak hanya ada Sepuluh Perintah Tuhan, melainkan terdapat pula lebih dari 600 peraturan yang diberikan Tuhan kepada komunitas bangsa Israel. Dalam etika Islam, hubungan antara agama, hukum, dan tindakan juga jelas. Smart (1998:19) menjelaskan hal tersebut, "Kehidupan Islam secara tradisional telah dikendalikan oleh Hukum atau syariah yang membentuk kehidupan moral suatu individu - menentukan bahwa ia harus salat setiap hari, memberikan zakat pada kaum miskin, dan lain sebagainya dan bahwa masyarakat harus memiliki berbagai institusi, seperti pernikahan, bentuk perbankan, dan lain-lainnya."

Umat Hindu juga memiliki ajaran etika yang kuat yang berhubungan langsung dengan agamanya. Seperti yang diungkapkan oleh Matthews (2007:91): "Ajaran Hindu kaya akan kode moral... Dalam kitab Weda, Rita merupakan dasar dari tatanan yang benar dalam alam semesta; semua hal sesuai dengan kontrolnya. Bagi seorang individu, dasar dari tindakan benar adalah darma. Darma adalah kesatuan Rita dalam kehidupan seseorang."

Bagi penganut Buddha, nilai etis dapat ditemukan dalam uraian Buddha tentang empat kebajikan besar yang harus dimiliki oleh semua orang, yaitu "kebajikan, rasa kasihan, bahagia atas kebahagiaan orang lain, dan ketenangan hati (Smart, 2000:9)." Walaupun dalam kata yang berbeda, namun inti pesannya tetap sama dengan yang ditemukan dalam tradisi lain. Matthews (2007:191) merangkum ajaran etika aliran Confusius sebagai berikut: "Manusia harus menghindari hal-hal yang mereka tidak ingin orang lain lakukan atas diri mereka. Mereka harus mengerjakan suatu hal yang sama seperti mereka melakukannya untuk diri mereka sendiri."

Semua agama mengajarkan untuk menghindari pembunuhan, pencurian, perkataan dusta, dan perzinahan. Semua agama mengajarkan pemeluknya untuk berlaku rendah hati, murah hati, jujur serta baik. Semua ini dilakukan demi memampukan diri mereka mencapai tujuan tertinggi dari kehidupan yaitu keselamatan, penebusan, pencerahan, pembebasan jiwa, kebahagiaan kekal.

\section{SIMPULAN}

Tradisi agama telah membentuk tata nilai yang tidak dapat dipisahkan dari kehidupan masyarakat pemeluknya. Berbagai instrumen sakral yang didirikan dan dilanggengkan oleh otoritas agama memperkuat proses pembentukan nilai dan pewarisannya. Kitab Suci, kegiatan ritual, ajaran- ajaran agama, kegiatan peribadatan dan khotbah menjadi saluran penanaman nilai dan pembentukan cara pandang yang sangat efektif. Sejarah panjang agama dengan penganutnya yang besar telah mengambil bagian dalam membentuk budaya dan peradaban dunia.

Tidak dapat dipungkiri bahwa nilai-nilai yang telah terintegrasi ke kehidupan para pemeluknya telah menentukan cara mereka hidup dan berinteraksi dengan orang-orang di sekitarnya. Dalam konteks seperti ini, agama sangat menentukan arah dan gerak zaman. Banyak ajaran mulia yang dibangun oleh agama. Hal ini menjadi berkat bagi alam semesta. Catatan yang perlu diperhatikan dalam hal ini adalah bahwa bagaimanapun juga sebagai institusi yang juga memiliki karakter dunia dan manusiawi, maka ajaran agama perlu pula dievaluasi 
secara kritis agar senantiasa mempromosikan nilai-nilai kehidupan yang luhur. Karena itu, sebagai pemeluk agama, sikap kritis terhadap ajaran agama perlu tetap dijaga. Pemikiran sempit yang hanya berfokus pada kepentingan sepihak sering mengarah kepada ajaran yang negatif terhadap dunia sekitar dan terhadap agama lain. Ajaran agama, dengan demikian, perlu melalui proses purifikasi sehingga sanggup menjadi berkat bagi semua orang dan alam semesta secara tidak terbantahkan.

Agama merupakan salah satu kekuatan sosial paling signifikan di dunia. Dengan kenyataan sejarah dan warisan yang panjang serta kenyataan bahwa agama-agama besar ini dianut oleh umat dengan populasi yang sangat besar, maka agama memainkan peran yang sangat menentukan dalam kehidupan sosial. Oleh karena itu, ajaran agama perlu diperhatikan secara serius. Kerendahan hati untuk mengevaluasi diri dan mengkritisi ajarannya agar menampilkan nilai-nilai yang universal dan membentuk cara pandang yang mulia merupakan harapan yang digantungkan dunia kepada para pemimpin agama dan para penganutnya.

\section{DAFTAR PUSTAKA}

Angrosino, M. V. 2004. The Culture of the Sacred: Exploring the Anthropology of Religion. Prospect Heights, IL: Waveland.

Braswell, G. W. Jr., 1994. Understanding World Religion. Nashville, $\mathrm{TN}$ :Broadman \& Holman.

Crystal, D., 2003. The Cambridge Encyclopedia of Language, Second Edition. New York: Cambridge University.

Grondona, M. 2000. A Cultural Typology of Economic Development, dalam Culture Matters: How Values Shape Human Progress, L. E. Harrison dan S. P. Huntington, ed. New York: Basic Books.

Haviland, W. A., Prins, H. E. L., Walrath, D., dan McBride, B. 2008. Cultural Anthropology: The Human Challenge, Twelfth Edition. Belmont, CA:Wadsworth.

Hoebel, E. A. 1958. Man in the Primitive World. New York: McGraw-Hill.

Ishii, S., Cooke, P., dan Klopf, D., 1999. Our Locus in the Universe: Worldview and Intercultural Misunderstandings/Conflicts. Dokkyo International Review, 12.

Malefijt, A. 1968. Religion and Culture: An Introduction to Anthropology of Religion. Prospect Heights, IL: Waveland.

Matthews, W. 2007. World Religions. Belmont, CA: Thomson Wadsworth.

McGuire, M. B., 2002. Religion: The Social Context, Fifth Edition. Belmont, CA: Wadsworth.

Nanda, S. 1994. Cultural Anthropology, Fifth Edition. Belmont, CA: Wadsworth.

Osborne, M. P. 1996. One World, Many Religions: The Ways of Worship. New York: Alfred A. Knopf.

Peoples, J. dan Bailey, G. 2006. Humanity: An Introduction to Cultural Anthropology, Seventh Edition. Belmont, CA: Thomson Wadsworth.

Richter, K. E., Rapple, E. M., Modschiedler, J. C., dan Peterson, R. 2005. Understanding Religion in a Global Society. Belmont, CA: Wadsworth.

Robinson, T. A. dan Rodrigus, H. 2006. World Religions: A Guide to Essentials. Peabody, MA: Hendrickson.

Smart, N. 2000. Worldview: Crosscultural Explorations of Human Beliefs, Third 
Edition. Upper Saddle River, NJ: Prentice Hall.

Walsh, B. J. dan Middleton, J. R. 1984. The Transforming Vision. Downers Grove, IL: InterVarsity Press. 